\title{
Faunal community structure of a chemoautotrophic assemblage on whale bones in the deep northeast Pacific Ocean
}

\author{
Bruce A. Bennett*, Craig R. Smith**, Bryce Glaser, Hilary L. Maybaum \\ Department of Oceanography, University of Hawaii at Manoa, 1000 Pope Rd, Honolulu, Hawaii 96822, USA
}

\begin{abstract}
Modern and tossil chemoautotrophic communitjes supported by organic-rich whale skeletons have been reported from the bathyal-abyssal seafloor in the eastern and western North Pacific. Based on studies with the research submersible ALVIN, we describe here general habitat characteristics, and macro- and megafaunal community structure of one such community, estimated to be $>4 \mathrm{yr}$ old, associated with an $18 \mathrm{~m}$ baleanopterid skeleton at $1240 \mathrm{~m}$ in the Santa Catalina Basin (SCB) off California, USA. The visible remains of the whale in 1988-91 consisted of partially buried skeletal material (primarily vertebrae and the head complex) with a plan area of approximately $7.9 \mathrm{~m}^{2}$ White and yellow mats of sulfur-oxidizing bacteria covered many of the bone surfaces, yielding an estimated mat area of at least $4.0 \mathrm{~m}^{2}$ Bone collections indicated a total attached macrofaunal community of at least 12490 individuals distributed among $\geq 43$ species, with 6 species with population sizes of $>1000$ individuals. Megafauna associated with the skeleton consisted primarily of the vesicomyid clam Vesicomya cf. gigas, with an estimated population size of 400 to 800 individuals. The whale-skeleton faunal community was taxonomically distinct from that of the surrounding SCB, with $>97 \%$ of its individuals belonging to species very rare or absent in background sediments. The whale-skeleton assemblage exhibited strong taxonomic and functional affinities to other deep-sea reducing habitats (e.g. hydrothermal vents and cold seeps), marked by a prominence of vesicomyid clams and mytilid mussels with sulfide-oxidizing, chemoautotrophic bacterial endosymbionts. In addition, 5 of the whalefall species (Pyropelta corymba, P. musaica, Bathykurila guaymasensis, Idasola washingtonia and Cocculina craigsmithi) also appear to occur at Juan de Fuca and/or Guaymas Basin hydrothermal vents, despite geographic separation of $-1800 \mathrm{~km}$. We conclude that whale falls may nurture substantial, sulfide-dependent communities at the deep-sea floor, and that some species may be dispersing to hydrothermal vents from whale-fall habitat islands.
\end{abstract}

KEY WORDS: Chemoautotrophy - Whale bones Benthos Deep sea Community structure

\section{INTRODUCTION}

Biological communities supported by chemoautotrophic production occur in a variety of reducing habitats at the deep-sea floor. Hydrothermal vents on spreading centers in the Pacific and Atlantic harbor high-biomass communities dependent on sulfuroxidizing bacteria (e.g. Grassle 1986, Rona et al. 1986, Tunnicliffe 1991); these assemblages frequently

\footnotetext{
- Present address: King County Surface Water Management Division, 700 Fifth Ave., Suite 2200, Seattle, Washington 98104, USA

*Addressee for correspondence
}

include mussels and clams that host chemoautotrophic bacterial endosymbionts (e.g. Cavanaugh 1983, Felbeck et al. 1983, Childress et al. 1987, Fisher 1990). Similar chemosynthetic communities fueled by sulfide or methare have been reported from sites of oil, brine or pore-water seepage associated with petroleum-rich sediments, subduction zones, carbonate scarps, turbidites and a submarine canyon in the Atlantic and Pacific Basins (Paull et al. 1984, Kennicutt et al. 1985. 1989, Kulm et al. 1986, Mayer et al. 1988, Sibuet et al. 1988, Embley et al. 1990). Clams hosting chemoautotrophic endosymbionts also occur in reducing sediments in deep basins off southern California (Felbeck et al. 1983, Vetter 1985, Distel et al. 1988). All of these 
deep-sea chemoautotrophic communities are dependent on the flux of reduced compounds (sulfide or methane) made available by specific geological features of their habitats.

We recently reported a deep-sea chemoautotrophic community fueled by an unexpected source of reduced compounds - the lipid-rich skeleton of a blue or fin whale resting on the bathyal seafloor off southern California (Smith et al 1989). Preliminary data indicated that this community (found in Santa Catalina Basin, SCB) includes mussels, clams and limpets with taxonomic affinities to the faunas of chemosynthetic communities at seeps and vents (Smith et al. 1989). Members of the SCB assemblage subsequently have been found on portions of 3 whale skeletons trawled from bathyal depths off central California (Smith et al. 1989, McLean 1992, W. Wakefield pers. comm.), and appear to be heavily encrusted on a lipid-rich skull collected in deep water off New Zealand (Marshall 1987). In addition, modern or fossil communities apparently dependent on chemoautotrophy have very recently been reported from (1) a whale skeleton found at $4037 \mathrm{~m}$ in the Bonin Trench by the 'Shinkai $6500^{\circ}$ in October, 1992 (K. Fujikura pers, comm.), (2) fossilized whale bones from the early Oligocene (35 million yr in age) from the Olympic Peninsula (Squires et al. 1991), and (3) possibly from the fossil skeletons of ichthyosaurs and plesiosaurs from the middle Jurassic (150 million yr ago; Martill et al. 1991). Thus, chemoautotrophic communities associated with whale, or large carcass, falls appear to be widely distributed in the modern ocean, and across geologic time.

Our discovery of the SCB whale-bone community, combined with calculations of the abundance of reductant-rich whale remains on the seafloor, prompted the hypothesis that whale skeletons may provide dispersal stepping stones for species dependent on reducing habitats at the deep-sea floor (Smith et al. 1989). Because the large whale species, in combination, are cosmopolitan (Braham 1984), whale falls can occur virtually anywhere on the seafloor; i.e. they are not restricted to the mid-ocean ridges or ocean margins that produce other deep-sea reducing habitats. Sunken whale bones may thus provide the only refugia for sulfide-based, chemoautotrophic communities over vast reaches of the open-ocean floor. The fossil record suggests that similar refugia may have been available for over 100 million yr (Martill et al. 1991).

To rigorously evaluate the importance of whale remains as chemoautotrophic habitats on the deep-sea floor, we need much better knowledge of (1) the community structure of whale-based sulfophilic assemblages, (2) the source and flux rates of reductants at whale falls, and (3) whale-fall community kinematics (e.g. community-development and persistence times)
We are employing the SCB whale-skeleton community as a case study to investigate these topics.

In this paper we describe the orientation of the SCB whale skeleton, and evaluate the species structure and population sizes of megabenthos, macrobenthos, and, to a limited extent, bacterial mats associated directly with the whale bones. We then compare the whale-skeleton community to the background community in $\mathrm{SCB}$, to the communities at deep-sea vents and seeps, and to communities at other organic-rich habitat islands. In future publications, we will address the reductant sources and fluxes, food-web structure and community dynamics in the SCB whale-skeleton community.

\section{STUDY AREA AND METHODS}

Study area. The whale skeleton discussed here lies at a water depth of $1240 \mathrm{~m}$ on the level floor of SCB $\left[33^{\circ} 12^{\prime} \mathrm{N}, 118^{\circ} 30^{\prime} \mathrm{W}_{i}\right.$ see Smith \& Hamilton (1983) and Allison et al. (1991) for maps of the area]. This basin has been the site of intensive studies of carbon flux, benthic community dynamics, and bioturbation over the past 14 yr [see references in K. Smith (1987), C. Smith (1992a), and Kukert \& Smith (1992)]. Bottomwater oxygen concentrations at this site are 18 to $23 \mu \mathrm{M}$ (K. Smith 1987, Archer et al. 1989); bottomwater temperature and salinity are $4.1^{\circ} \mathrm{C}$ and $34.4 \%$, respectively (Emery 1960). The surface sediment is a poorly sorted silty clay with a disaggregated median grain size of about $4.0 \mu \mathrm{m}$ (Emery 1960); in situ median grain size falls between 250 and $500 \mu \mathrm{m}$ due to sediment pelletization (Kukert \& Smith 1992). Sediment organic carbon content is relatively high (-5.8\%; Smith 1986), and oxygen penetrates only to sediment depths of 5 to $10 \mathrm{~mm}$ (Archer et al. 1989); however, pore-water sulfide concentrations normally appear to remain low $(<1 \mu \mathrm{M})$ to depths of $10 \mathrm{~cm}$. (C. Smith et al. unpubl.). For a detailed description of the benthic environment in SCB, see Smith \& Hamilton (1983).

Field methods. The whale remains were discovered during ALVIN dive no. 1949 in November 1987; the remains lie within the bounds of a transponder net established at the SCB floor in 1985 to facilitate relocation of long-term experiments. We returned to the site with ALVIN in November 1988 (dive nos. 2132 to 2138) and in February 1991 (dive nos. 2331 to 2336) to conduct further whale-fall studies. During the latter 2 dive series, data were collected via photographic surveys, close-up stereophotography, retrieval of bone samples, and scoop-net and Ekman core sampling of sediment fauna. The data presented in this paper, except for those pertaining to macrofauna attached to bones, were primarily collected during the November 1988 dive series; because bone collections were inadequate 
in 1988, data for attached macrofauna are derived primarily from the 1991 dive series.

Survey photographs were obtained using 2 camera systems; a Photosea 2000 stereo-metric camera and strobe mounted downlooking (camera axis vertical when ALVIN was level) on the front of ALVIN's basket, and ALVIN's sponson cameras set in the 'up-two' position. The Photosea system was used to conduct flyover surveys of the whale and adjacent sediments; prior to the first flyover, numbered scale markers $(10 \times 30 \mathrm{~cm}$ rectangular PVC plates) were dropped at 7 locations along the length of the skeleton to provide a reference scale. We then endeavored to fly ALVIN very slowly (speed $\sim 0.1$ knot) along the axis of the skeleton with the Photosea camera at an altitude of $3 \mathrm{~m}$; the camera was fired approximately every $10 \mathrm{~s}$ from a manual switch inside the submersible. Because of difficulties in holding ALVIN neutrally buoyant, flyover altitudes varied from. about 0.5 to $5.5 \mathrm{~m}$.

Large numbers of survey photographs of the whale skeleton and immediately adjacent sediments were obtained with the sponson cameras while ALVIN was on the bottom working around the skeleton. To compare the whale-skeleton megafauna with that in the background community, 3 photographic transects were also conducted using the sponson cameras. Each transect heading (Fig 1) was selected at random from within a different $120^{\circ}$ sector of a circle centered on the whale remains. Transects began at approximately $4 \mathrm{~m}$ from the skeleton to avoid disturbance of the remains; the ALVIN pilot was then instructed to ski along the bottom on the pre-selected heading at a speed of 1 knot while the sponson cameras fired automatically every $8 \mathrm{~s}$. Based on ALVIN's video data records, submersible headings varied by as much as $100^{\circ}$ and submersible speed varied by up to 0.4 knots within a phototransect; thus, transect lengths were estimated using ALNAV transpondernavigation fixes (accuracy $\pm 10 \mathrm{~m}$ ) for the beginnings and ends of transects. Inter-photograph spacing within transects was then calculated by dividing estimated transect length by the number of photographs within the transect.

Additional high-quality photographs were obtained of the whale bone and adjacent sediments by mounting the Photosea stereocamera and strobe on the front of ALVIN's basket, looking downward at about a $45^{\circ}$ angle. A half-inch $(\sim 12 \mathrm{~mm})$ diameter PVC scale rod protruded from the camera, parallel to its axis, to a distance of $80 \mathrm{~cm}$; prior to manual firing of the camera, the end of this rod was placed in contact with the object of interest to insure image focus. In addition, ALVIN's manipulator video camera and hand-held cameras within the submersible were used to obtain highquality images of the whale remains.

Bones used to estimate the abundance of attached macrofauna were carefully lifted from the seafloor by ALVIN's manipulator and each placed separately into a water-tight container to prevent washing during ALVIN's ascent and recovery. The containers for vertebra $V-1$ and $V-18$ failed to close completely, so counts from these bones must be considered minima. Once on shipboard, bones were photographed while in their container water, and then carefully removed to the ship's laboratory; visible attached macrofauna on bones were immediately mapped, and then picked off and preserved in a $10 \%$ buffered formalin-seawater solution. Residues in the bottoms of bone containers were washed on $300 \mu \mathrm{m}$ sieves and fixed in $10 \%$ buffered formalin. After $\geq 24 \mathrm{~h}$, fixed samples were transferred to $80 \%$ ethanol.

Scoop nets used to sample vesicomyid clams in sediments adjacent to whale bones had a rigid circular hoop of $22 \mathrm{~cm}$ outside diameter and netting with a stretch mesh of $\leq 2 \mathrm{~cm}$. These were used in ALVIN's manipulator to scoop horizontally to a depth of 10 to $20 \mathrm{~cm}$. The approximate area sampled with each scoop-net deployment was estimated to be $0.1 \mathrm{~m}^{2}$ from flyover photographs (see methods below, and Fig. 1).

Laboratory methods. Photographs from the downlooking Photosea camera were used to produce a map of the whale skeleton (Fig. 1). The map was constructed by tracing film images projected by a modified Beseler enlarger A common known scale was maintained throughout mapping by overlaying scale markers and other recognizable features occurring in consecutive photographs. Measurements of scale markers indicated linear-measurement errors of up to approximately $20 \%$; in most areas (e.g. along the vertebral column), errors were $<10 \%$

All animals recognizable in photographs were assumed to be living unless obviously dead (e.g by exhibiting gaping or broken shells). Large $(\geq 1 \mathrm{~cm}$ diameter) white spots were frequently seen on the sediment surface around the whale remains; such spots were not observed in background sediments during this, or previous, studies in SCB (Smith \& Hamilton 1983, Smith 1985). Close-up photographs and visual observations indicated that these white spots were primarily fragments from vesicomyid shells. Thus, we counted these spots from our flyover photographs to provide insights into the spatial scale of the whalebone reducing community. Our estimates of the abundance and population size of living clams are based on (1) positive identifications of clams in close-up stereophotographs, and (2) collections of living clams in scoop-net samples.

Large pieces of white and yellow material flaked off whale bones manipulated by ALVIN; this material has been identified as microbial mats (Deming et al. 1990 , in press). Using down-looking photographs, we mapped 

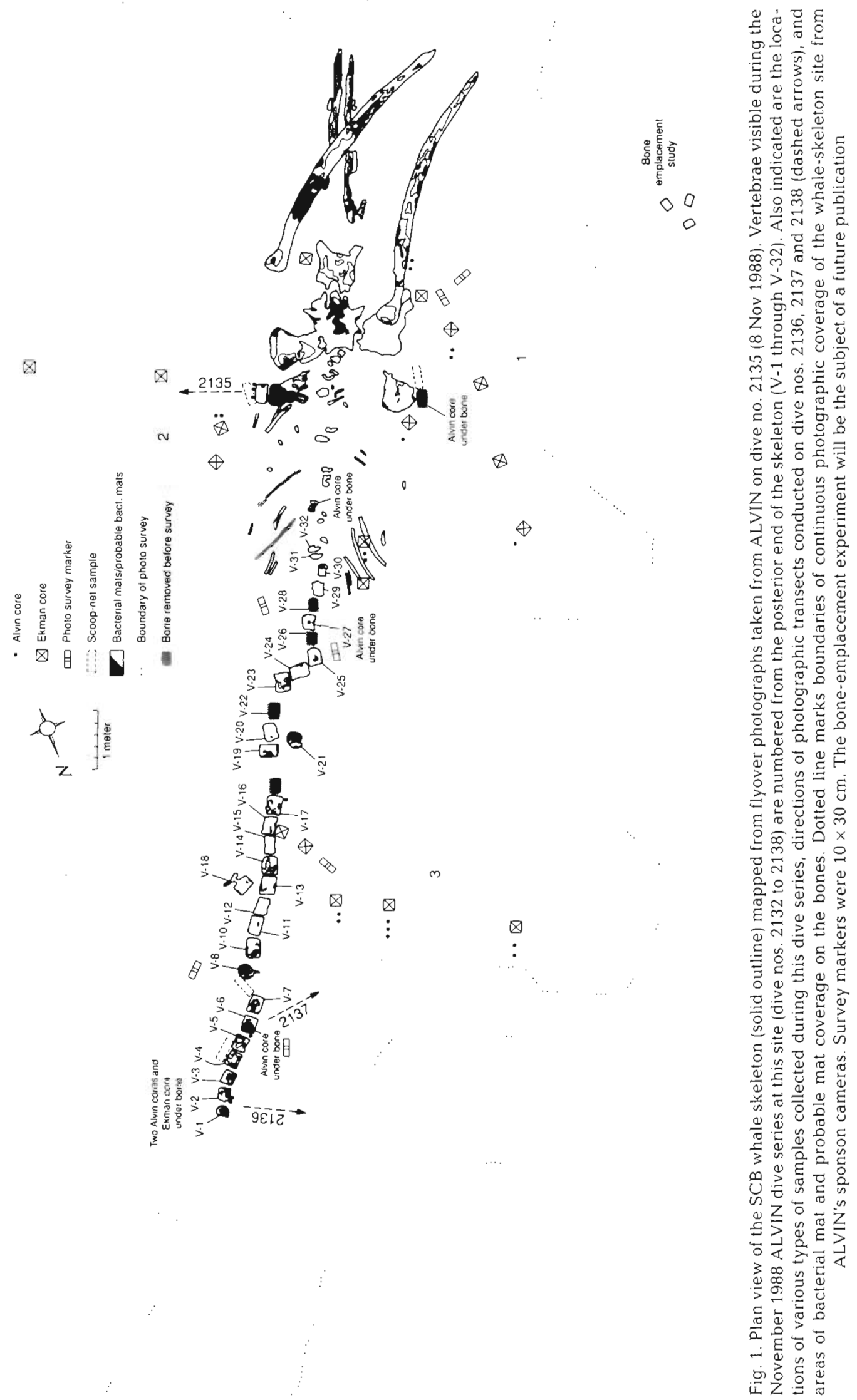
the plan area of the whale skeleton covered by 'mats', 'probable mats' and 'mat-free' surfaces, again using the Beseler enlarger. 'Mat' areas were covered with a readily visible, fluffy white or yellow layer of material (Figs. 2 \& 3). 'Probable mats' were areas in which the bones or sediment appeared to be covered with a thin film of whitish material that looked neither like sediments, which were brown, nor bare bone, which was gray or brown; the film-like quality was probably indicative of low densities of microbial filaments. Plan area of bone covered by 'mats' and 'probable mats' was estimated by weighing cutouts of paper maps.

The anterior and posterior ends of vertebrae were poorly visible in flyover photographs (their flat surfaces were essentially normal to the angle of view) so we evaluated bacterial-mat coverage of these surfaces from close-up photographs obtained from the Photosea camera mounted on the front of ALVIN's basket. Bacterial mats (both white and yellow) were easily recognized in these photographs (e.g. Fig. 2C); their distribution on vertebral ends were mapped with the Beseler enlarger system. The proportion of vertebral end area covered by mats was estimated by weighing paper cutouts of mapped mat and non-mat zones; absolute areal coverage of these mats was obtained by multiplying this proportion by bone-end area measured on recovered bones (see below).

The abundance of epibenthic megafauna in survey photographs obtained from ALVIN's sponson cameras were quantified using a Canadian (or perspective) grid [see Smith \& Hamilton (1983) and Wakefield \& Genin (1987) for methods]. Measurements of scale markers using this grid indicated errors in linear measurements of $\leq 10 \%$. Ophiuroids were relatively difficult to distinguish in photographs and thus were counted only in the front $1 \mathrm{~m}^{2}$ area of the grid; larger megafauna were counted over a $6 \mathrm{~m}^{2}$ area (cf. Smith \& Hamilton 1983). Identifications of background megafaunal species were based on Smith \& Hamilton (1983). Megafaunal densities along transects and at the whale-fall site were compared using $t$-tests corrected for multiple comparisons (Hartley \& Pearson 1950, Armitage \& Berry 1987).

Surface areas (on a cm scale) of 4 recovered vertebrae ( 1 from 1987 and 3 from 1991) were measured by covering bones with a single smooth layer of aluminum foil that was subsequently weighed. Bone surfaces that had been exposed above the sediment-water interface were easily distinguished from the dark-stained surfaces lying below sediments, allowing us to measure exposed and complete surface area for each vertebra. We multiplied the mean exposed and complete areas of measured bones by the number of large vertebrae present in the skeleton during our visits in 1988 and 1991 (26 and 22 , respectively) to estimate total exposed and complete surface area on large vertebrae at these times. Means were used because linear-regression analyses revealed no significant relationship ( $p>0.20$ ) between bone surface area and vertebral number for the recovered bones.

Macrofauna removed from recovered whale bones were measured, using an ocular micrometer, under a dissecting microscope. Reference material was identified by the following systematists: R. Turner and R. Vrijenhoek (mytilids and vesicomyids), $T$ Waller (pectinids), J. McLean (gastropods), R. Hessler (isopods), M. Pettibone, J. Blake, and J. Bailey-Brock (polychaetes), A. Williams (galatheids). Additional identifications are still pending for amphipods

\section{RESULTS}

\section{Size and orientation of the skeleton}

In 1988 (and 1991), the visible remains of the whale consisted solely of skeletal material partially buried in sediment with ventral side up (Fig. 1). We estimate the plan area of visible bones to have been $7.9 \mathrm{~m}^{2}$ (with $-95 \%$ confidence limits, CL, of 5.1 to $11.5 \mathrm{~m}^{2}$ ); vertebrae and head bones contributed the bulk of this plan area (Fig. 1). The size and structure of the visible ventral portion of skull bones (Figs. $1 \& 2$ ) indicated the remains are those of a blue whale Balaenoptera musculus or fin whale Balaenoptera physalus (D. Rice pers. comm.). The recognizable skeleton spanned approximately $18 \mathrm{~m}$; however, approximately 10 caudal vertebrae appeared to be missing (see Omura 1971), presumably due to bone degradation or burial. Inclusion of missing vertebrae yields an approximate live length of $21 \mathrm{~m}$, and a live weight of 55000 to $57000 \mathrm{~kg}$ (Lockyer 1976).

In 1988 (and 1991) the whale skeleton appeared to be relatively intact. Bones occurring out of skeletal alignment (Fig. 1) apparently had been displaced by ALVIN prior to flyover-photographic mapping conducted on dive no. 2135; videotapes from the whale discovery dive (no. 1949) show the skeleton in near perfect alignment (Allison et al. 1991). While all exposed bone surfaces appeared to have sustained some erosion (Allison et al. 1991; Figs. 2 \& 3), bones in the central region of the skeleton appeared the most heavily damaged and/or buried; vertebrae in the cervical and thoracic regions extended only slightly above the sediment-water interface. In addition, only 7 or 8 pairs of ribs were visible suggesting that an additional 7 or 8 pairs (Tomilin 1967) were buried or completely degraded. Several skull bones, and those of the pectoral fins (ulna, radius and phalanges) also remained undetected. Despite this degradation, the cores of recovered vertebrae were laden with lipids in both 1988 and 1991 (Allison et al. 1991, C. Smith et al. unpubl.); in addition recovered vertebrae and ribs smelled strongly of sulfide. 

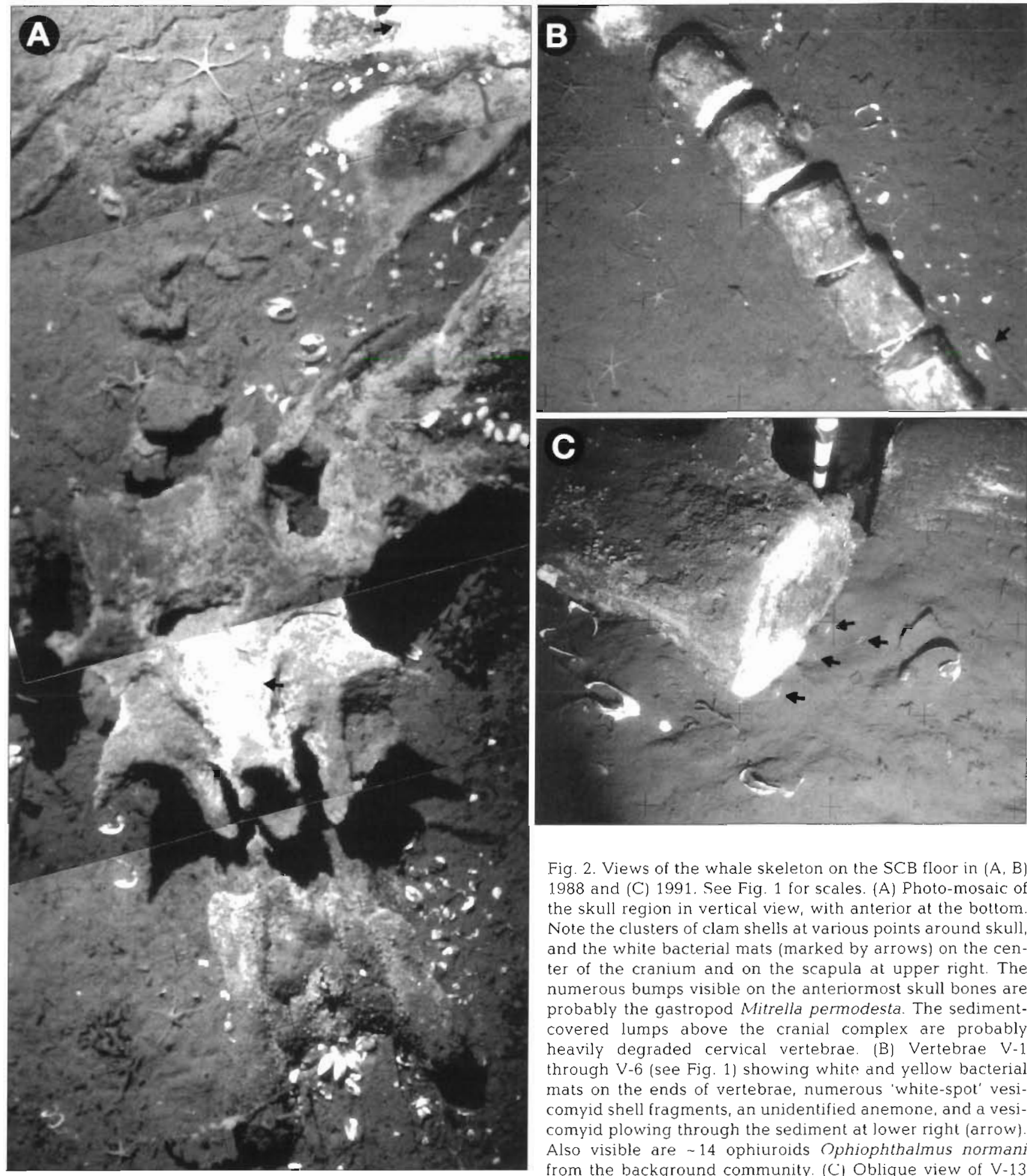

Fig. 2. Views of the whale skeleton on the SCB floor in $(A, B)$ 1988 and (C) 1991. See Fig. 1 for scales. (A) Photo-mosaic of the skull region in vertical view, with anterior at the boltom Note the clusters of clam shells at various points around skull, and the white bacterial mats (marked by arrows) on the center of the cranium and on the scapula at upper right. The numerous bumps visible on the anteriormost skull bones are probably the gastropod Mitrella permodesta. The sedimentcovered lumps above the cranial complex are probably heavily degraded cervical vertebrae. (B) Vertebrae $V$ - 1 through $V-6$ (see Fig. 1) showing white and yellow bacterial mats on the ends of vertebrae, numerous 'white-spol' vesicomyid shell fragments, an unidentified anemone, and a vesicomyid plowing through the sediment at lower right (arrow) Also visible are -14 ophiuroids Ophiophthalmus normani from the background community. (C) Oblique view of $\mathrm{V}-13$ showing microbial mats (white areas), and black sulfidic areas on the end of the vertebra. Visible macrofauna include numerous $M$. permodesta (mostly on the vertebral end) and the limpet $P$ yropelta corymba (on the blackened areas on the end of the vertebraej. In addition, the siphons and/or valves of 4 live vesicomyid clams are visible slightly protruding above the sediment near the end of the vertebra (arrows) Also visible are fragmented valves from dead vesicomyids 

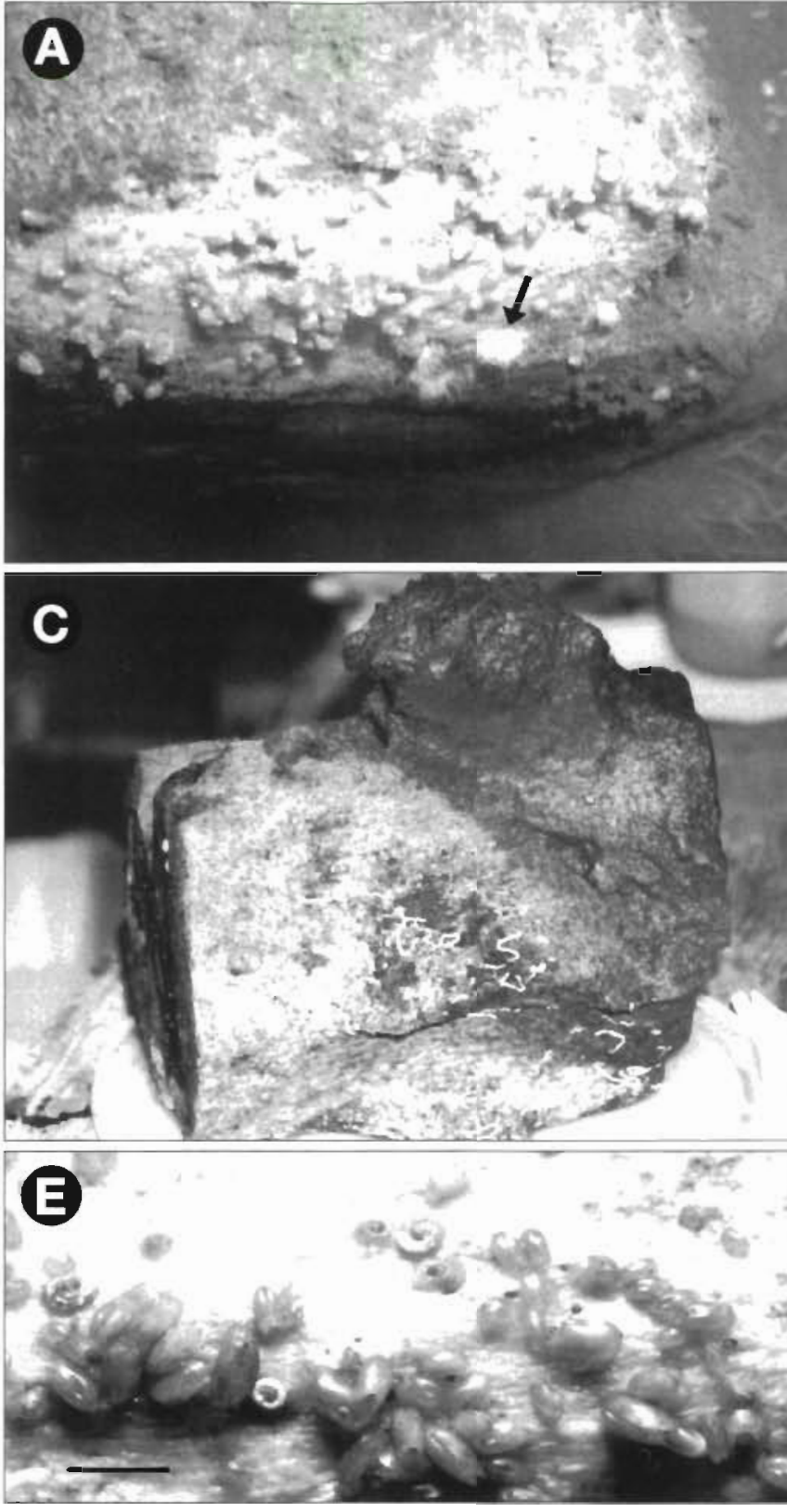

Fig. 3. Photographs of whale bones shortly after recovery from the SCB skeleton. (A) Oblique view of the end of vertebra V-27 while submerged in water in the collection bucket in November 1988. Note clusters of the snail Mitrella permodesta (on pink areas of bone) and tufts of Beggiatoa (arrow) For scale, maximum length of $M$. permodesta is $-1 \mathrm{~cm}$ (B) End view of vertebrae V-21 collected in February 1991 White areas of bone are covered with Beggiatoa filaments. Small white spots on the blackened, sulfidic area of the bone are the limpet Pyropelta corymba. Also visible in the upper right portion of the bone are several Cucculina craigsmithi limpets, one with a calcareous serpulid tube coiled on its shell. Several small serpulid tubes are also visible attached directly to the bone. For scale, width of the vertebra is $\sim 30 \mathrm{~cm}$. (C) Lateral view of V-21 with dorsal process upward. The upper right corner of the bone was buried and is thus covered with sediment. Tubes of $>30$ serpulids, and a single Delectopectin randolphi (left center of bone) are visible. Note that no macrofauna are visible on the previously buried portion of the bone. For scale, the vertebra is $\sim 35 \mathrm{~cm}$ long
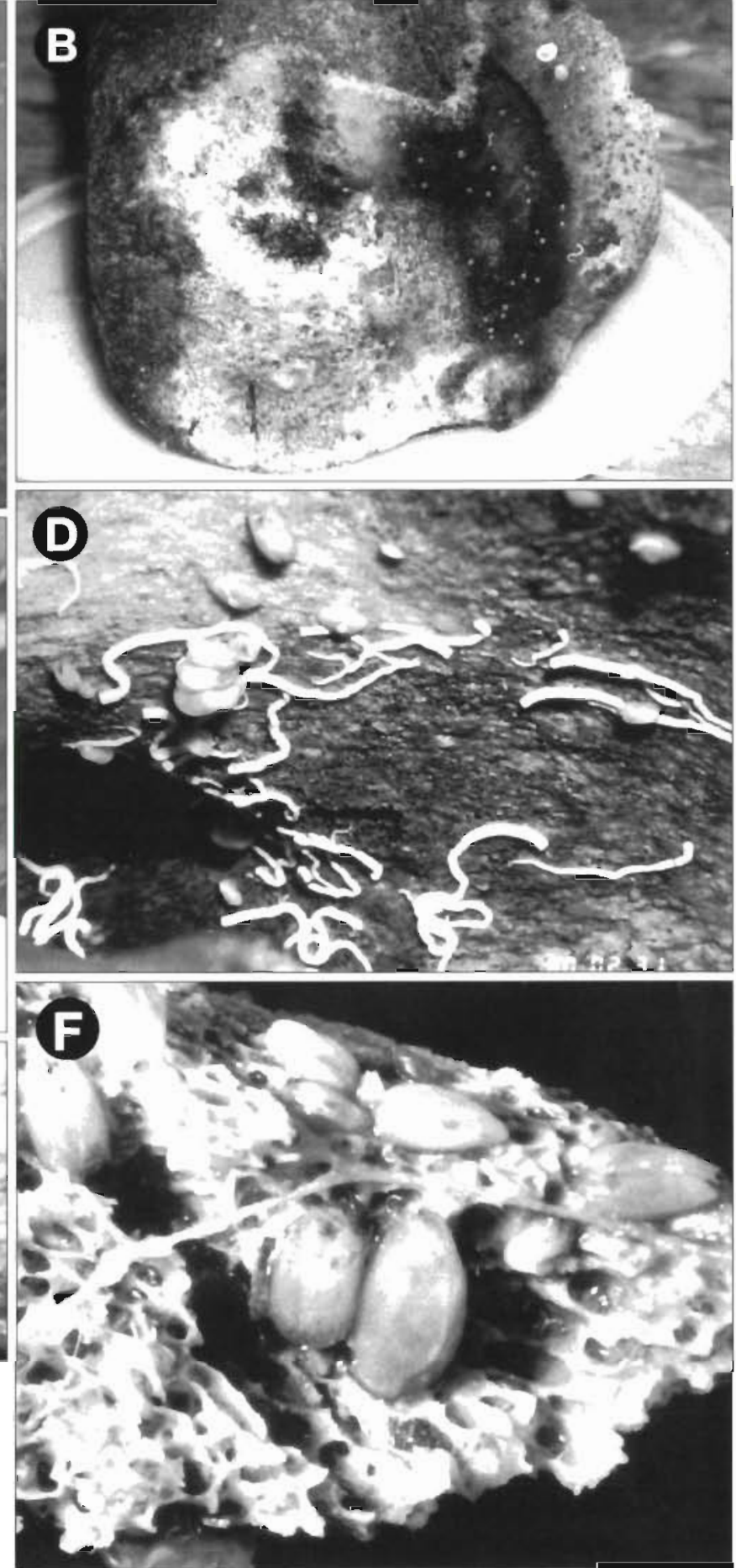

(D) Close-up of an exposed portion of vertebra $V$-18, recovered in February 1991. Visible are numerous serpuhd tubes, a cluster of 4 Idasola washingtonia mussels (towards upper left). and several solitary $C$. craigsmithi and $I$. washingtonia. For scale, the largest $l$. washingtonia in the cluster is $-8 \mathrm{~mm}$ long. (E) Close-up of a rib recovered in November 1988, with clusters of $I$. washingtonia and a few $C$. craigsmithi. This portion of the bone was above the sediment-water interface and was pink. Scale marks are $1 \mathrm{~cm}$. (F) Close-up of heavily eroded end of rib, recovered in November 1988. Note I. washingtonia nestled into crevices, presumably seeking concentrations of sulfide. The largest mussels here are $\sim 1 \mathrm{~cm}$ long 


\section{Distribution of microbial mats}

A diverse assemblage of sulfur bacteria, including filaments of Beggiatoa (Deming et al. 1990, in press) occurred as white and yellow mats on exposed bone surfaces; on one occasion, microbial mats were observed to extend several centimeters onto the sediment-water interface (Figs. 2 \& 3). Visible mats were fairly evenly distributed along the length of the skeleton, except that they were largely absent from the buried or highly degraded ribs and vertebrae in the thoracic region (Fig. 1). The heaviest mat coverage appeared to occur on the anterior and posterior ends of vertebrae (Figs. $2 \& 3$ ); no evidence of bacterial mats was observed on bone surfaces originally lying below the sediment-water interface.

Bacterial mats on the skeleton mapped from flyover photographs covered a total plan area of $1.3 \mathrm{~m}^{2}(-95 \%$ $\mathrm{CL}=0.8$ to $1.9 \mathrm{~m}^{2}$ ) and probable mats covered an additional plan area of $1.4 \mathrm{~m}^{2}\left(\sim 95 \% \mathrm{CL}=0.9\right.$ to $\left.2.0 \mathrm{~m}^{2}\right)$; this corresponds to about $34 \%$ of total skeleton plan area. An average of $70.8 \%(\mathrm{SE}=11.3, \mathrm{n}=4)$ of the exposed end areas of vertebrae visible in close-up photographs were covered with continuous microbial mats. For recovered vertebrae originally lying horizontally on the sediment (Table 1), the average end area exposed above the sediment-water interface was $0.078 \mathrm{~m}^{2}$ (SE $=0.016 \mathrm{~m}^{2}, \mathrm{n}=3$ ); this, combined with the total of 23 horizontal vertebrae in the skeleton in 1988 (Fig. 1) yields $1.3 \mathrm{~m}^{2}$ of microbial mats on vertebral ends not measured in flyover photographs.

In summary, our best quantitative estimate of total mat area on the SCB skeleton in 1988 is $4.0 \mathrm{~m}^{2}$. This is very likely to be a substantial underestimate because bone surfaces were not really planar, and because many bone surfaces were not visible in ALVIN photographs.

\section{Macrofauna attached to bones}

ALVIN observations and photographs indicated that exposed surfaces of vertebrae, ribs and head bones often were heavily encrusted with a variety of macrofaunal animals (e.g. Figs. 2 \& 3). However, we were unable to reliably identify and count macrofauna in any in situ photographs, so our estimates of attached macrofaunal densities and population sizes are derived from vertebrae recovered in 1991.

A total of 1855 individuals from $\geq 42$ species were recovered from the 4 vertebrae quantitatively sampled in 1991 (Table 2). Of this total, only 6 individuals (1 Mitrella permodesta, 2 pyropeltids, and 3 Cocculina craigsmithi) were removed from bone surfaces lying below the sediment-water interface; the whale-bone
Table 1. Surface area of vertebrae recovered from the SCB whale skeleton. Original locations of vertebrae are shown in Fig. 2. 'Exposed area' is the sum of bone surfaces lying above the sediment-water interface; 'submerged areas' were buried within the sediment

\begin{tabular}{|cccc|}
\hline Bone \# & $\begin{array}{c}\text { Total area } \\
\left(\mathrm{cm}^{2}\right)\end{array}$ & $\begin{array}{c}\text { Exposed area } \\
\left(\mathrm{cm}^{2}\right)\end{array}$ & $\begin{array}{c}\text { Submerged area } \\
\left(\mathrm{cm}^{2}\right)\end{array}$ \\
\hline V-1 & 3620 & 1590 & 2030 \\
V-6 & 4250 & 1910 & 2340 \\
V-18 & 5610 & 3860 & 1750 \\
V-21 & 3670 & 1930 & 1740 \\
& $\bar{X}=4290$ & $\bar{x}=2320$ & $\bar{x}=1970$ \\
& $\mathrm{SE}=460$ & $\mathrm{SE}=520$ & $\mathrm{SE}=460$ \\
\hline
\end{tabular}

macrofauna overwhelmingly occurred on surfaces directly exposed to bottom water. A similar pattern was noted, nonquantitatively, for macrofauna attached to recovered ribs (Fig. 3). Patterns of macrofaunal abundance on the exposed vertebral surfaces were patchy, but exhibited no obvious orientation to the sedimentwater interface; dense patches occurred both within a few centimeters of the sediment and tens of centimeters above it (Fig. 3). The most striking pattern was near-total absence of all macrofauna from yellow and white microbial mats occurring on the anterior and posterior ends of vertebrae; in contrast $C$. craigsmithi and the pyropeltids appeared to aggregate on blackened (presumably sulfidic) areas on vertebral ends, while $M$. permodesta exhibited highest densities on pink, uneroded areas of bone (Fig. 3).

Total macrofaunal abundance varied dramatically ( 7 -fold) between the 4 collected vertebrae (Table 2); probably due to small sample size $(n=3)$, this total abundance was not significantly correlated with exposed bone surface area (product moment correlation coefficient $r=0.79 ; p>0.05$; Sokal \& Rohlf 1981). The 6 most abundant species (each with total frequencies $>100$ ), Idasola washingtonia, Mitrella permodesta, Pyropelta musaica, P. corymba, Cocculina craigsmithi, and Ilyarachna profunda, were heterogeneously distributed among the 4 vertebrae ( $\mathrm{p} \ll 0.01$ for the $G$-test; Sokal \& Rohlf 1981). In particular, $P$. musaica and $P$. corymba were at least twice as common per unit exposed surface area on $\mathrm{V}-18$ as on any other vertebra; in contrast, $I$. washingtonia and $C$. craigsmithi exhibited especially high densities on V-21 (Table 2). This heterogeneity in abundance among vertebrae may reflect habitat preferences (e.g. vertebrae may have varying availabilities of food in the form of bone lipids or bacterial populations), or it might result from population founder effects.

The estimated total macrofaunal community abundance on the 22 whale vertebrae present at the site in 1991 is 12480 individuals (Table 2); estimated verte- 
Table 2. Abundance of macrofauna attached to vertebrae recovered from the SCB whale skeleton in 1991 Densities are given per $1000 \mathrm{~cm}^{2}$ of exposed bone area. For V-15, surface-area measurements were unavalable so the mean exposed bone area from Table 1 was used to calculate densities. Macrofaunal population sizes on the total of 22 vertebrae present in 1991 are estimated by multiplying mean number of undividuals per collected vertebra times 22

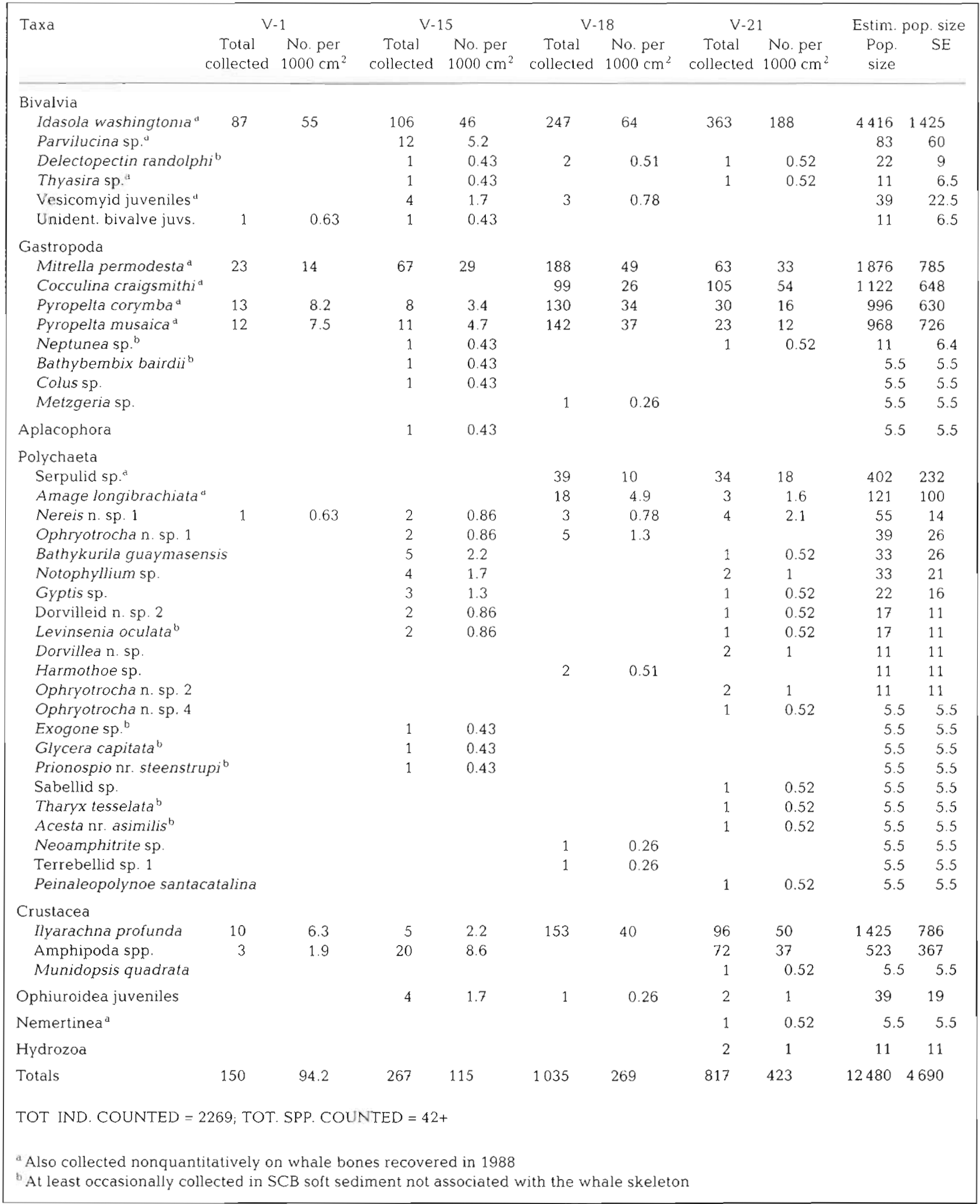


bral population sizes for individual species ranged from 5.5 to 4420 (Table 2). Those calculations are likely to yield substantial (perhaps 2-fold) underestimates of macrofaunal population sizes on the full skeleton because the concentrations of macrofauna on the ribs, skull, and other miscellaneous bones, which constituted $>50 \%$ of skeleton plan area (Fig 1), are not included, and portions of these bones were heavily encrusted with macrofauna (Figs. 2 \& 3).

Size-frequency distributions of the 5 dominant macrofaunal species on the vertebrae collected in $1991 \mathrm{ex}$ hibit several patterns (Fig. 4). Small-to-mid-sized individuals predominate in all 5 species, suggesting recent recruitment. Results from bone-implantation experiments at this site (C. Smith et al. unpubl.) indicate that such sizes for all 5 species can be attained within 27 mo. In addition, all 5 species exhibit low abundance in the largest size classes; this pattern is most pronounced in Idasola washingtonia and the pyropeltid limpets. Finally, at least 2 species (Cocculina craigsmithi and Pyropelta corymba) exhibit hints of multiple peaks in their size-frequency distributions, suggesting that recruitment and/or mortality may be pulsed.

\section{Distribution of megafauna}

We recognized $\geq 25$ types of megafauna in our survey photographs (Table 3); only 1 type, the vesicomyid clams, was strongly associated with the whale skeleton. Approximately $94 \%$ of the living and dead vesicomyid clam shells that we collected in scoop net and grab samples $(\mathrm{n}=30)$ were Vesicomya cf. gigas; the remaining $\sim 6 \%$ were Calyptogena cf. pacifica. Thus, the vast bulk of the living and dead vesicomyids observed around the skeleton are likely to have been $V$. cf. gigas.

Living vesicomyid clams were observed or collected in at least 8 locations along the length of the skeleton in 1988 and 1991 (Fig. 5). At all these sites, living clams were only recorded within $20 \mathrm{~cm}$ of whale bones, either in adjacent or underlying sediments, or (occasionally) atop large bones such as the cranial complex. Relatively intact dead clam shells also occurred along the entire length of the skeleton, but again were restricted to within several decimeters of emergent or buried bones (e.g. Fig. 2). On average, $77 \%$ of shells collected in scoop nets near the bones were from dead clams (Table 4).

In typical living position, vesicomyids were nearly completely buried in the sediment, with the siphons and $\leq 1 \mathrm{~cm}$ of shell protruding (Fig. 2); frequently they occurred at the end of trails in the sediment $(3$ to $5 \mathrm{~cm}$ wide, several $\mathrm{cm}$ deep. and up to $\sim 4 \mathrm{~m}$ long) apparently formed by clams during horizontal burrowing. On at least 2 occasions, we observed live clams protruding half-way out of the sediment, with the umbo upward, at the end of freshlooking trails; this may be the posture assumed by clams when moving across the seafloor.

To estimate the population size of vesicomyid clams at the skeleton, we calculated the area of seafloor around the bones inhabited by clams (the 'clam habitation zone'), and then estimated clam densities within this zone using 2 independent approaches. Assuming that vesicomyids only occurred within $20 \mathrm{~cm}$ of emergent or buried large whale bones (e.g. vertebrae, ribs, and cranial and jaw bones; Fig. 5), these clams inhabited a total seafloor area of $28 \mathrm{~m}^{2}(\sim 95 \%$ confidence limits of 18 to $40 \mathrm{~m}^{2}$ ). Scoop net samples within this zone yielded a mean of 27 clams per $\mathrm{m}^{2}$ (Table 4). Close-up stereophotographs indicated a mean of 2.7 clams visible in half the periphery of a vertebra (Table 5); assuming that each vertebra is $0.2 \times 0.3 \mathrm{~m}$ in plan view (Fig. 5) and that live clams occur to distances of $20 \mathrm{~cm}$ from vertebrae, the clam habitation zone' per half vertebra is roughly 0.3 by $0.7 \mathrm{~m}$. This yields a minimum clam density estimate of

$$
\text { (2.7) }(0.3 \mathrm{~m} \times 0.7 \mathrm{~m})^{-1}=13 \mathrm{~m}^{-2} \text {. }
$$

(standard error $=4$ ). Based on these density calculations, we estimate that the total clam population size within the $28 \mathrm{~m}^{2}$ clam habitation zone was roughly 400

Table 3. Megafaunal species recognizable in ALVIN survey photographs of the SCB floor and whale bones

\begin{tabular}{|cc|}
\hline Porifera & Echinodermata \\
Hexactinellida, 2 spp. & Asteroidea \\
Cnidaria & Brisingidae, 1 sp. \\
Anthozoa & Henricia sp. \\
Actinoscyphia sp.? & Pteraster sp. \\
Unidentified anemone, 1 sp. & Crinoidea, 1 sp. \\
Gorgonacea, 1 sp. & Echinoidea, 1 sp. \\
& Holothuroidea \\
Mollusca & Pannychia sp. \\
Pelecypoda & Scotoplanes globosa \\
Pectinidae, 1 sp. & Ophiuroidea \\
Vesicomya cf. gigas & Ophiomusium lymani \\
Gastropoda & Ophiopholis kennerleyi \\
Bathybembix bairdii & Ophiophthalmus normani \\
Neptunia amianta & Chordata \\
Arthropoda & Agnatha \\
Decapoda & Eptatretus deani \\
Pandalopsis ampla & Chondrichthyes \\
& Raja trachura \\
& Osteichthyes \\
& Anoplopoma fimbria \\
& Sebastolobus altivells \\
& Zoarcidae, 1 sp. \\
\hline
\end{tabular}



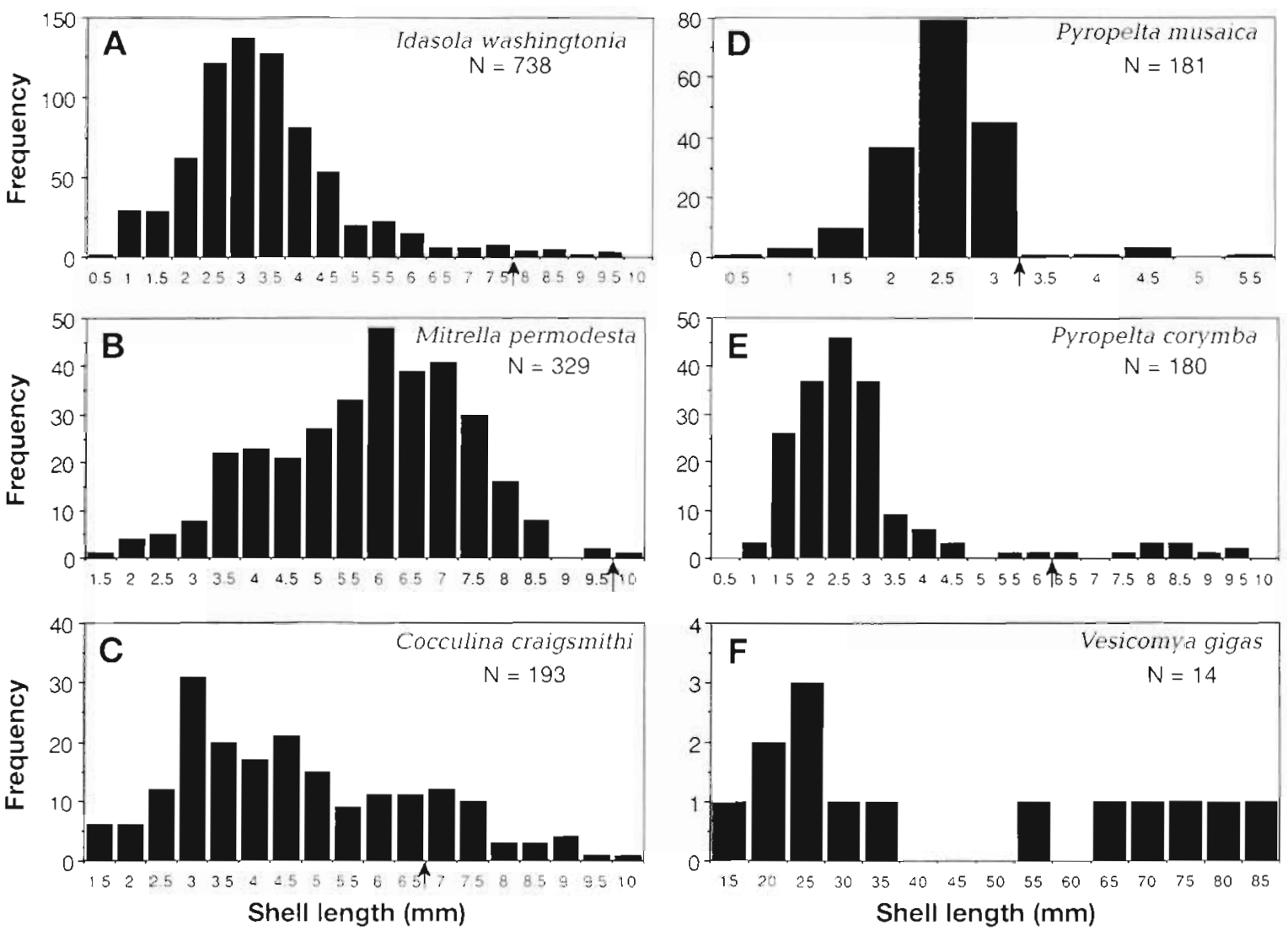

Fig. 4. Size-frequency distributions of (A to E) dominant macrofauna collected from vertebrae in 1991, and of (F) Vesicomya cf. gigas collected in 1988 from sediments at the SCB whale skeleton. (A) Idasola washingtonia, (B) Mitrella permodesta, (C) CuCculina cralgsmithi, (D) Pyropelta musaica, (E) Pyropelta corymba, and (F) Vesicomya cf. gigas. Arrows on the $x$-axes of (A) to (E) indicate the maximum sizes attained by these species on whale bones experimentally placed on the seafloor for 27 mo

to 800 individuals. Considering that only $23 \%$ of clam shells collected came from living individuals (Table 4), we estimate that a minimum of 1700 to 3400 vesicomyid clams have lived (not necessarily synchronously) within this $28 \mathrm{~m}^{2}$ area.

Table 4. Number of vesicomyid clams, and percentage of live shells collected in scoop net samples around whale bones in 1988 and 1991 Scoop nets each sampled a plan area of about $0.1 \mathrm{~m}^{2}$ to depths of 10 to $20 \mathrm{~cm}$. Locations sampled by scoop nets are indicated in Fig. 1

\begin{tabular}{|lccc|}
\hline Location of scoop & $\begin{array}{c}\text { ALVIN } \\
\text { dive no. }\end{array}$ & $\begin{array}{c}\text { No. of live } \\
\text { clams collected }\end{array}$ & $\begin{array}{c}\text { Percent } \\
\text { live shells }\end{array}$ \\
\hline Outside of eastern scapula & 21.33 & 4 & 14 \\
Adjacent to western humerus & 2135 & 3 & 40 \\
East side of V-1 & 2136 & 0 & 0 \\
Between $V-7$ and $V-8$ & 2137 & 0 & 0 \\
West side of $V-4$ and $V-5$ & 2138 & 7 & 59 \\
Beneath $V-18$ & 2333 & 4 & 25 \\
West side of $V-15-V-19$ & 2336 & 1 & $?$ \\
& & $\bar{X}=2.7$ & $\bar{X}=23 \%$ \\
& & $\mathrm{SE}=1.0$ & $\mathrm{SE}=10 \%$ \\
\hline
\end{tabular}

Based on a limited sample size, the Vesicomya cf. gigas population in 1988 exhibited a broad range in body size, with dominance in the smaller size classes (Fig. 4).

Clam shell fragments, as indicated by 'white spot' counts, were distributed over a much larger seafloor area than were visible living clams, occurring to distances of several meters from the bones (Fig. 5). In addition, the abundance of these fragments was quite patchy, with a notable concentration on the eastern side of the skull bones. This patchiness is consistent with a past larger clam habitation zone, possibly related to the previous presence of whale soft tissue on the seafloor Horizontal mixing of shell fragments, e.g. due to the activities of ophiuroids (Wheatcroft 1991), would be expected to yield a more random distribution of shell fragments

Epibenthic megafauna common on the surrounding SCB floor (Smith \& Hamilton 1983) was not strongly attracted to the whale bones in 1988. Only 4 Ophiophthalmus normani and 


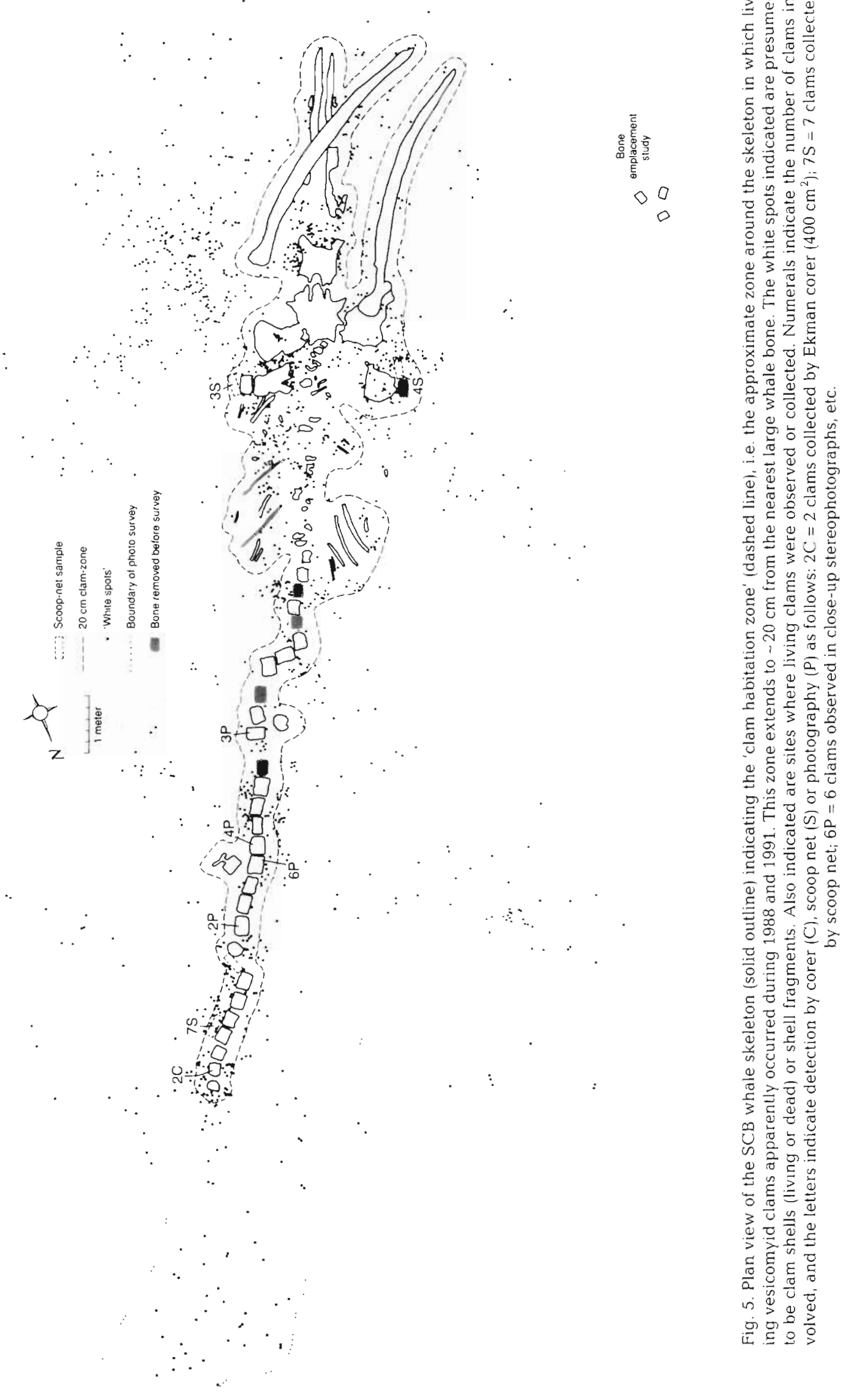


1 large unidentified anemone (Actinoscyphia sp.) were photographed directly on bones: in addition several O. normani, a single rockfish Sebastolobus altivelis and a hexactinellid sponge appeared to rest against bones. The summed abundance of the 4 dominant background species was about $30 \%$ lower within a $1 \mathrm{~m}$ radius of whale bones than on the general basin floor (Table 6); this likely reflects megafaunal avoidance of bones and immediately adjacent sulfidic sediments. Phototransects to distances of 520 to $940 \mathrm{~m}$ from the whale revealed no evidence of far-field effects on the abundance of the 4 dominant background megafaunal species (Table 6).

\section{Taxonomic composition of whale-bone macrofauna and megafauna}

The estimated $\geq 13000$ individuals and $\geq 43$ species of macrofauna and megafauna attached to, or clearly associated with, the whale bones fall predominantly into

Table 5. Counts of living vesicomyid clams visible in close-up stereophotographs around vertebrae. Only vertebrae in which at least half of the periphery was visible to a distance of $\geq 30 \mathrm{~cm}$ were counted

\begin{tabular}{|lccc|}
\hline $\begin{array}{l}\text { Vertebra } \\
\text { no. }\end{array}$ & $\begin{array}{c}\text { Year } \\
\text { photo- } \\
\text { graphed }\end{array}$ & $\begin{array}{c}\text { Portion of vertebra } \\
\text { visible }\end{array}$ & $\begin{array}{c}\text { No. of clams } \\
\text { visible per } 1 / 2 \\
\text { vertebra }\end{array}$ \\
\hline V-2 & 1988 & East side and posterior end & 0 \\
$V-3$ & 1988 & East side and posterior end & 1 \\
$V-9$ & 1988 & East side and posterior end & 2 \\
$V-12$ & 1991 & East side and posterior end & 6 \\
$V-13$ & 1991 & West side and posterior end & 4 \\
$V-18$ & 1988 & West side and posterior end & 3 \\
& & & $\bar{x}=2.7$ \\
& & & $\mathrm{SE}=0.9$ \\
\hline
\end{tabular}

a limited number of high-level taxonomic groups (Table 7). Bivalves plus gastropods constitute nearly $80 \%$ of the total abundance; of these, nearly half are the mytilid Idasola washingtonia. Species richness is distributed differently, with $51 \%$ of species falling within the polychaetes (Table 7); 3 other 'groups', i.e. bivalves, gastropods and miscellaneous taxa (which includes Crustacea), constitute at least $12 \%$ of the species.

\section{Persistence of whale-bone macrofaunal and megafaunal populations}

Although quantitative estimates of attached macrofaunal population sizes are not feasible for whale bones recovered in 1987 and 1988, photographs (Fig. 3) and semi-quantitative bone pickings indicate that many of the dominant species in 1991 were also present in large numbers (population sizes $>100$ ) in 1987 and 1988. Species recovered in high abundance in 1988 included Idasola washingtonia, which encrusted many ribs and vertebrae (Fig 3), Mitrella permodesta, Cocculina craigsmithi, Pyropelta musaica, $P$, corymba, and the serpulid sp. Other macrofaunal species present at least in low abundance included Amage longibranchiata and Lucinoma annulata. In 1987, I. washingtonia, C. craigsmithi and the serpulid sp. encrusted a recovered rib and vertebrae. In addition, Vesicomya cf. gigas was present at the whale skeleton in 1988 and 1991, and apparently during the whale discovery dive in November 1987 (Smith et al. 1989). Thus, at least a significant portion of the whaleskeleton community persisted on these bones from November 1987 to February 1991 (i.e. for $39 \mathrm{mo}$ ).

Table 6. Mean abundance per $\mathrm{m}^{2}$ of epibenthic megafauna within $1 \mathrm{~m}$ of the whale skeleton, and along phototransects beginning $4 \mathrm{~m}$ from the skeleton. Included are (a) abundances of the 4 megafaunal species constituting $>1 \%$ of total epibenthic megafaunal abundance in the background community, and (b) total epibenthic megafaunal abundance. Lengths of phototransects were as follows: No. $2135=620 \mathrm{~m}$, No. $2136=940 \mathrm{~m}$, No. $2137=520 \mathrm{~m}$

\begin{tabular}{|c|c|c|c|c|c|c|c|c|}
\hline \multirow{3}{*}{ Organism(s) } & \multirow{2}{*}{\multicolumn{2}{|c|}{$\begin{array}{l}\text { Within } 1 \mathrm{~m} \\
\text { of skeleton } \\
(\mathrm{n}=91)^{\star}\end{array}$}} & \multicolumn{6}{|c|}{ Background community } \\
\hline & & & \multicolumn{2}{|c|}{$\begin{array}{c}\text { Transect } 2135 \\
(\mathrm{n}=156)^{\circ}\end{array}$} & \multicolumn{2}{|c|}{$\begin{array}{l}\text { Transect } 2136 \\
(n=234)^{\circ}\end{array}$} & \multicolumn{2}{|c|}{$\begin{array}{l}\text { Transect } 2137 \\
\quad(\mathrm{n}=129)^{\mathrm{a}}\end{array}$} \\
\hline & $\dot{\bar{x}}$ & SD & $\bar{x}$ & SD & $\bar{x}$ & $\mathrm{SD}$ & $\bar{x}$ & $\mathrm{SD}$ \\
\hline OphiophthaImus normani & 4.6 & 3.0 & 5.0 & 2.2 & $6.4^{\circ}$ & 2.6 & $5.8^{\circ}$ & 2.7 \\
\hline Ophiopholis kennerleyi & 0.5 & 0.8 & $1.5^{\circ}$ & 1.1 & $1.7^{\circ}$ & 1.2 & $1.4^{\circ}$ & 1.1 \\
\hline Ophiomusium lymani & 0.10 & 0.34 & $0.24^{\circ}$ & 0.49 & $0.40^{\circ}$ & 0.63 & $0.27^{\circ}$ & 0.53 \\
\hline Bathybembix bairdii & 0.13 & 0.40 & 0.06 & 0.10 & 0.09 & 0.12 & 0.07 & 0.12 \\
\hline Total megafauna & 5.5 & 3.4 & $7.1^{\circ}$ & 2.3 & $8.8^{\bullet}$ & 2.8 & $7.8^{\bullet}$ & 3.0 \\
\hline
\end{tabular}


Table 7. High-level taxonomic composition of macrofauna and megafauna associated with the whale skeleton in SCB

\begin{tabular}{|lcc|}
\hline Taxon & $\begin{array}{c}\text { Percent of } \\
\text { total abundance }\end{array}$ & $\begin{array}{c}\text { Percent } \\
\text { of species }\end{array}$ \\
\hline Bivalvia & 40 & 14 \\
(Mytilidae) & $(33)$ & $(2)$ \\
(Vesicomyidae) & $(5)$ & $(5)$ \\
Gastropoda & 38 & 19 \\
(Archeogastropoda) & $(24)$ & $(9)$ \\
Polychaeta & 6 & 51 \\
(Dorvilleidae) & $(0.6)$ & $(12)$ \\
(Polynoidae) & $(0.4)$ & $(7)$ \\
Amphipoda & 4 & 2 \\
Isopoda & 11 & 12 \\
Miscellaneous & 1 & \\
a Total abundanre of whale-skeleton macrofauna and \\
megafauna is estimated at 13 080 individuals \\
o Total species richness of whale skeleton macrofauna and \\
megafauna is $\geq 43$ species. For percentage calculations, a \\
total of 43 species was used \\
c Amphipoda species are currently being identified; here \\
we assume conservatively that only 1. amphipod species \\
occurs on the whale bones
\end{tabular}

\section{DISCUSSION}

It is clear that the SCB whale skeletor formed a habitat island (cf. Brown \& Dinsmore 1988) colonized by a microflora and fauna strikingly atypical for SCB. During more than 30 ALVIN dives, 5 ROV (Remotely Operated Vehicle) deployments, and numerous camera surveys, neither microbial mats nor the fragments and trails of vesicomyid clams have been observed either on the open SCB floor, or associated with hard structures resting on the seabed (e.g. discarded chart cabinets, naval practice bombs and glass jars) (Smith \& Hamilton 1983, Smith 1985, Smith et al. 1986, Wheat-

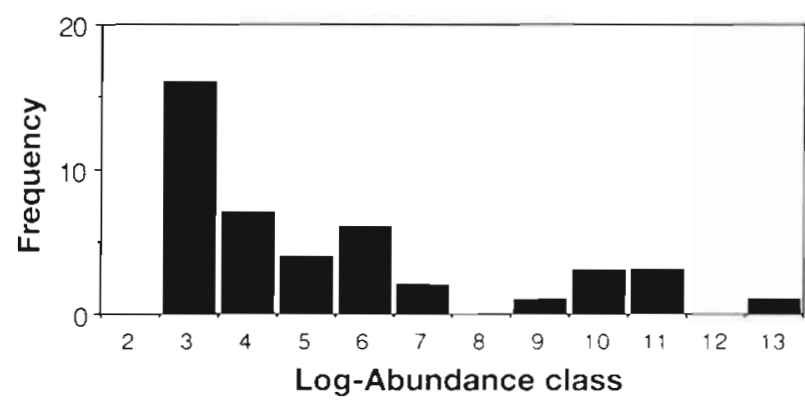

Fig. 6. Frequency distribution of estimated population sizes of macro-and megafaunal species associated with the SCB whale skeleton in 1988 and 1991. Log-abundance classes are based on powers of 2 as follows: class 2 includes species with population sizes between $2^{1}$ and $2^{2}$, class 3 includes population sizes between $2^{2}$ and $2^{3}$, etc. Taxa for which species distinctions are not avallable (e.g. the Amphipoda) are not included here croft et al. 1989, Kukert \& Smith 1992, C. R. Smith pers. obs.). In addition, 5 of the 6 most abundant macrofaunal species on the whale bones (which constitute $>90 \%$ of the whale-bone fauna) have remained uncollected during extensive sampling of background SCB sediments, and the sixth species (Ilyarachna profunda) is very rare (Smith 1983, 1986, Kukert 1989). While 12 species found at least occasionally in background $\mathrm{SCB}$ sediments were collected on the skeleton, they constituted less than $2.5 \%$ of the total whale-bone macrofaunal abundance. Such a difference between assemblages on hard substrates (i.e. whale bones) and in surrounding sediments is not necessarily surprising (cf. Mullineaux 1987); however, the whale-bone fauna also appears to be distinct from SCB hard-substrate communities. Only 1 of the 7 dominant whale-bone species, the serpulid sp., may occur in any abundance on hard SCB substrates (Smith \& Hamilton 1983, Mullineaux 1988, McLean 1992, Pettibone 1993, C. R. Smith pers. obs.).

Interestingly, the frequency distribution of abundances of macrofaunal species on the SCB whale skeleton (Fig. 6) appeared to exhibit a bimodal pattern similar to that on carrion and dung assemblages in terrestrial environments (Hanski 1986, Doube 1987); such bimadal patterns are rare in natural communities (Hanski 1986). Bimodality suggests that the whaleskeleton assemblage may have been composed of a mixture of abundant 'core' species adapted specifically to high-sulfide or whale-bone niches, and scarce 'satellite' species only marginally able to survive in this habitat (cf. Hanski 1986, Doube 1987). The presence of 'core' species suggests that this habitat type has persisted over evolutionary time (Hanski 1986).

The unusual species structure, and the restriction of the SCB whale-skeleton fauna to the immediate bone vicinity, indicates an ecology dependent on the whalebone habitat. This dependence is most likely to be nutritional. At least 5 nutritional modes could conceivably be supported by the whale skeleton: (1) direct feeding on primary whale-bone organic material (e.g. lipids); (2) grazing on free-living bacteria, or their byproducts, growing on the bones heterotrophically or chemoautotrophically; (3) chemoautotrophy supported by reduced inorganic compounds (e.g. sulfide) released by anaerobic microbial degradation of bone organics; (4) predation on the concentrated biomass of metazoa living on the bones; (5) suspension feeding in the higher current velocities afforded by bone protrusion into the benthic boundary layer (e.g. Jumars \& Gallagher 1982, Genin et al. 1986).

Because whale bones, including these from $\mathrm{SCB}$, typically are very rich in lipids [up to $60 \%$ by weight (Allison et al. 1991, S. Macko unpubl., C. Smith et al. unpubl.)], the bone biota may directly consume bone 
oils; in addition, these organisms could consume other organic components of the bone matrix. Thus far, we have not identified any metazoan species, e.g. whalebone sipunculans (Gibbs 1987), thought to feed directly on bone organic material, although it is certain that anaerobic and aerobic bacteria within the bone matrix fill this niche (Allison et al. 1991, Deming et al. in press). The pyropeltid and cocculinid limpets, and perhaps Mitrella permodesta, are presumed to be bacterial grazers feeding on sulfur-oxidizing filaments growing on the whale bones (Marshall 1987, McLean 1992), and thus to utilize the second nutritional mode. The ampharetid polychaete Amage longibranchiata is probably a surface deposit feeder (Fauchald \& Jumars 1979), also functioning essentially as a grazer of bacteria (and other particles) on bone surfaces. The third nutritional mode, that of chemoautotrophy based on reduced inorganic compounds such as sulfide, is employed (at least facultatively) by free-living bacteria within the Beggiatoa mats, and by endosymbiotic bacteria living in the tissues of the vesicomyid and lucinid clams, and Idasola washingtonia (Smith et al. 1989, Deming et al in press, C. Smith et al. unpubl.). No obvious predators of metazoa have been identified in the specialized whale-bone fauna, although the rare galatheid crabs and neptunid gastropods, and perhaps $M$. permodesta, likely fill this fourth nutritional niche. The fifth nutritional mode, that of suspension feeding, apparently is employed in part by I. washingtonia (C. Smith et al. unpubl.), and by the serpulid polychaete. In summary, the whale skeleton potentially supports a variety of nutritional modes, with the dominant faunal components exploiting sulfidebased, chemoautotrophic production via endosymbiosis or direct bacterial grazing (C. Smith et al. unpubl.). Thus, the SCB whale-skeleton habitat has strong functional similarities to other deep-sea reducing habitats at hydrothermal vents and cold seeps (Gage \& Tyler 1991. Tunnicliffe 1991).

Although the whale-skeleton community in 1988 (and 1991) clearly constituted a substantial organic enrichment at the SCB floor in the form of whale-bone lipids and bone-community biomass, there appeared to be no local enhancement of the background megafaunal community at the whale-fall site. This result is somewhat surprising in view of the apparent attraction of background megafauna to at least some cold seep sites (e.g. Juniper \& Sibuet 1987, MacDonald et al. 1989), and the omnivorous nature of the general SCB megafauna, particularly the ophiuroid Ophiophthalmus normani (Smith 1983, 1985, Smith \& Hamilton 1983). It may be that the concentrations and/or fluxes of noxious sulfides on whale-bone surfaces were high enough to preclude opportunistic feeding on bacterial mats, and the shells of the abundant whale-bone molluscs render them relatively predator resistant.
In addition to functional similarities, the SCB whalebone fauna exhibited taxonomic affinities to other deep-sea communities that utilize chemoautotrophic production. At higher taxonomic levels, the whalebone community showed broad overlap with the specialized faunas of eastern Pacific vents and seeps, with a prominence of vesicomyid and mytillid bivalves, archeogastropods, and polynoid, dorvilleid, and serpulid polychaetes (Van Dover 1990, Gage \& Tyler 1991, Tunnicliffe 1991, 1992). There were also lowlevel taxonomic affinities between the bone fauna and other deep-sea chemoautotrophic assemblages. Allozyme studies of vesicomyid clams suggest that Vesicomya cf. gigas from the whale skeleton falls within a cluster of species from hot vents and cold seeps ( $R$. Vrijenhoek pers. comm.). Two of the archeogastropod species from the SCB and central California whale bones, Pyropelta musaica and P. corymba, were described, respectively, from Juan de Fuca and Guaymas Basin hydrothermal fields (McLean 1992); in fact, the family containing these species (Pyropeltidae) was originally considered endemic to vents (McLean \& Haszprunar 1987, Tunnicliffe 1992). The polynoid Bathykurila guaymasensis found on the SCB whale skeleton (Pettibone 1993), and its subfamily Branchinotogluminae, were also described from vent habitats (Tunnicliffe 1992). In addition, Idasola washingtonia is reported (at low densities) from Guaymas Basin and possibly Juan de Fuca vents ( $R$. Turner pers. comm.), as well as from wood falls from the North and South Pacific (Dell 1987), and the limpet Cocculina craigsmithi apparently occurs at Juan de Fuca vents (Tunnicliffe pers. comm.). Finally, Lucinoma annulata and $M$. permodesta abound in low-oxygen basins off southern California (e.g. Felbeck et al. 1983, Vetter 1985, Distel et al. 1988, Carey et al. 1989, J. McLean pers. comm.), and $M$. permodesta also occurs at Monterey Canyon seeps (J. Barry pers. comm.).

In summary, there is evidence that whale-bone assemblages are related to sulfophilic faunas at reducing habitats ranging from vents to wood accumulations; whale falls likely yield habitats with intermediate levels of sulfide flux and habitat hostility, while hot vents and wood falls represent the ends of the spectrum. Interesting, the whale-bone communities off the California coast appear to share more species with distant vent communities (e.g. Juan de Fuca Ridge and Guaymas Basin, which are $>1800 \mathrm{~km}$ away) than with the more proximal seep systems on the California slope (e.g. Kennicutt et al. 1989, Embley et al. 1990. J. Barry pers. comm.). It may be that the ephemeral island habitats provided by vents and whale falls select for similar life-history characteristics (e.g. high dispersal ability, rapid maturation) that are not as well suited to the more persistent cold seeps; 
alternatively, California cold-seep habitats may simply be undersampled for macrofauna. In any case, at present one cannot reject the hypothesis that some species (e.g. Pyropelta corymba, P. musaica, Bathykurila guaymasensis, Idasola washingtonia and Cocculina craigsmithi) may be dispersing to vent-seep systems via whale falls.

In addition to vent-seep affinities, some species found on the SCB skeleton are likely to represent specialists on deep-sea whale bones. While we did not collect osteopeltid limpets or sipunculans thought to be whale-bone endemics (Gibbs 1987, Marshall 1987), a number of the whale-bone polychaete species were new to science (Table 2). Included in these are 2 species from the family Polynoidae, 5 from Dorvilleidae, and 3 from Nereidae (Pettibone 1993, J. Blake \& B. Hilbig unpubl.); the first 2 families contain many species that specialize on organic-rich habitats in deepsea and shallow-water environments (Pearson \& Rosenberg 1978, Desbruyeres et al. 1980, Desbruyeres \& Laubier 1988, Pettibone 1993, J. Blake pers. comm.). However, because deep-sea habitats, especially hard substrata, are in general very poorly sampled, and because many of the macrofaunal species in the deep sea remain undescribed (e.g. Grassle \& Maciolek 1992), we can only postulate that these polychaetes are whale-bone endemics.

The structure and sizes of the bone-fauna populations provide some interesting insights into the nature of the SCB whale-skeleton habitat. First, the broad range in sizes of the limpets, Mitrella permodesta, Idasola washingtonia, and Vesicomya cf. gigas, combined with growth rates of bone fauna on bone implantation experiments (C. Smith et al. unpubl.), suggest that recruitment has continued on the SCB whale skeleton over a period of years. The predominance of small individuals in the populations of most of these species (Fig. 5) is consistent with initial light recruitment on the whale skeleton from external propagule sources, followed by 'reseeding' by local populations. If this is the case, many of the populations may still have been in a growth phase in 1991 (i.e. 3.3 yr after the skeleton-community discovery and $>6$ yr after community initiation; Smith et al. 1989). Alternatively, higher mortality on larger size classes (e.g. due to size-selective predation) could yield a relative abundance of small individuals. We favor the recruitment explanation for most species (excluding $M$. permodesta) because we found little evidence of limpet or mussel mortality (e.g. empty shells) in surrounding sediments ( $\mathrm{H}$. Maybaum \& C. Smith unpubl.). In contrast, large $M$. permodesta shells were common in the near-bone sediments $(\mathrm{H}$. Maybaum \& C. Smith unpubl.) suggesting that this species may suffer sizeselective mortality.
Population-size estimates for the whale-bone fauna are also of interest because they indicate that the community utilizing chemoautotrophic production at the whale skeleton was surprisingly large. The vesicomyid clam population was estimated at 400 to 800 individuals; because $73 \%$ of clam shells collected around the skeleton were dead, at one time the population may have been even larger. A population of 400 to 800 clams is greater than many cold-seep clam clusters (e.g. Juniper \& Sibuet 1987, Sibuet et al. 1988, Embley et al. 1990), and comparable in size to the vesicomyid populations at small- to medium-sized hydrothermal vents (e.g. Hessler et al. 1985, 1988). Other sulfophilic components of the SCB whale-skeleton community, including mussels and limpets, apparently attained population sizes in the thousands. We know of no population estimates for similar macrofaunal components at seeps and vents, but again we suspect that the whale-skeleton populations were comparable in size to macrofaunal populations at small- to medium-sized seep and vent sites (cf. Grassle 1986, Gage \& Tyler 1991, Tunnicliffe 1991)

Because the SCB whale-bone community was supported by the remains of a large whale species, the sulfophilic assemblage may have been bigger than those that develop on the sunken remains of smaller species such as gray whales Eschrichtius robustus. Assuming that the sulfophilic fauna was supported by energy derived from bone lipids (Smith 1992b, C. Smith et al. unpubl.), and that bone surface area (which scales to body-length squared) ultimately limits community size, the skeletons of adult gray whales (11 to $15 \mathrm{~m}$ in length; Rice et al. 1984) should support whale-bone communities $\sim 30$ to $50 \%$ of the size of the SCB assemblage. This rough calculation suggests the skeletons of gray whales, and other similarly sized species such as bowhead, right, humpback and sperm whales (Lockyer 1976), could also support sizable chemosynthetic assemblages, with macrofaunal population sizes in the 100 's to 1000's. Better documentation of deep-sea whale-skeleton communities, and their limiting factors, are highly desirable to confirm these speculative numbers. Nonetheless, existing evidence suggests that individual whale falls may produce sizable chemosynthetic habitats, and yield substantial numbers of sulfophilic faunal propagules at the deep-sea floor.

Finally, it should be noted that the communities on sunken whale carcasses are likely to be dynamic, passing through several stages of chemical and biological succession over periods of months to years. Successional stages on deep-sea whale falls are likely to include at least the following: (1) a scavenger-aggregation phase during which necrophages from the surrounding community le.g. lysianassid amphipods, rattails, hagfish, ophiuroids (e.g. Isaacs \& Schwartzlose 1975, Smith 
1985)] feed on the soft tissues of recently arrived whale carcasses; (2) a transitional stage, during which the principal utilizers of whale-carcass organic material shift from aerobic metazoan scavengers to anaerobic bacterial decomposers, such as sulfate reducers [because sulfide is highly toxic to most higher organisms (Somero et al. 1989), such a shift to microbial decomposition may well occur prior to exhaustion of soft tissue by scavengers (e.g. Schäfer 1972, pers. obs. on shallow-water carcasses)]; (3) a sulfophilic-community stage similar to that described here for the SCB skeleton, which includes animal populations that are sustained by chemoautotrophic production fueled by sulfides (and other reduced chemicals) derived from anaerobic microbial decomposition (Smith et al. 1989, Deming et al. in press). In the absence of further data, the duration of the first 2 successional stages for whale falls can only be the topic of speculation. However, the third, chemoautotrophic stage apparently was present on the SCB skeleton from November 1987 to February 1991, and Smith et al. (1989) estimated that it was at least 3 yr old in 1987. Thus, chemoautotrophic assemblages may persist on whale bones for $>6$ yr. Further elucidation of the nature and rates of succession on sunken whale carcasses will require more extensive time-series studies of whale remains at the deep-sea floor.

Acknowledgements. We thank the many people who assisted in the field including $\mathrm{S}$. Brumsickle, H. Kukert, S. Doan, F. Dobbs, R. Pope, S. McCarthy, S. Vink, S. Garner, P. Parnell and members of the J. Deming laboratory. The ALVINATLANTIS II crews provided their usual outstanding support. R. Hessler generously loaned oceanographic gear and provided sage advice. S. Garner provided substantial assistance in the laboratory. We also thank the previously listed taxonomists for their help in faunal identifications, J. Barry for providing unpublished Monterey seep species lists, and 3 anonymous reviewers for useful comments on the manuscript. This research was supported by NSF grants OCE-9000162 and OCE-90-22116. This is contribution no. 3542 from the School of Ocean and Earth Science and Technology, University of Hawail at Manoa.

\section{LITERATURE CITED}

Allison, P. A., Smith, C. R., Kukert, H., Deming, J. W., Bennett, B. A. (1991). Deep-water taphonomy of vertebrate carcasses: a whale skeleton in the bathyal Santa Catalina Basin. Paleobiology 17: 78-89

Archer, D., Emerson, S., Smith, C. R. (1989). Direct measurement of the diffusive sublayer at the deep sea floor using oxygen microelectrodes. Nature 340:623-626

Armitage, P., Berry, G. (1987). Statistical methods in medical research. Blackwell Scientific, Oxford

Braham, H. (1984). The status of endangered whales: an overview. Mar. Fish. Rev. 46: 2-6

Brown, M., Dinsmore, J. J. (1988). Habitat islands and the equilibrium theory of island biogeography: testing some predictions. Oecologia 75: 426-429
Carey, S. C., Vetter, R. D., Felbeck, H. (1989). Habitat characterization and nutritional strategies of the endosymbiontbearing bivalve Lucinoma aquizonata. Mar. Ecol. Prog Ser. 55: 31-45

Cavanaugh, C. M. (1983). Symbiotic chemoautotrophic bacteria in marine invertebrates from sulphide-rich habitats. Nature 302: 58-61

Childress, J. J., Felbeck, H., Somero, G. N. (1987). Symbiosis in the deep sea. Scient. Am. 256: 115-120

Dell, R. K. (1987). Mollusca of the Family Mytilidae (Bivalvia) associated with organic remains from deep water off $\mathrm{New}$ Zealand, with revisions of the genera Adioicola Dautzenborg, 1927 and Idasola Iredale, 1915. Natn. Mus. N.Z. Rec. 3: $17-36$

Deming J., Reysenbach, A. L., Macko, S. A., Smith, C. R. (in press). The microbial diversity at a whale fall on the seafloor: bone-colonizing mats and animal-associated symbionts. Microsc. Res. Tech.

Deming, J. W., Reysenbach, A. L., Neimer, D. J., Macko, S. A., Smith, C. R. (1990). Microbial associations with megafauna colonizing a whale carcass on the sea floor: specific analogs to hydrothermal vent environments. EOS 71: 92

Desbruyeres, D., Bervas, J. Y., Khripounoff, A. (1980). Un cas de récolonization rapide d'un sédiment profond. Oceanol. Acta 3: 285-291

Desbruyeres, D., Laubier, L. (1988). Exploitation d'une source de matière organique concentrée dans l'océan profond: intervention d'une annélide polychéte nouvelle. C.r. Acad. Sci. 307: 329-335

Distel, D., Lane, D., Olsen, G. Giovannoni, S., Pace, B., Pace, N., Stahl, D., Felbeck, H. (1988). Sulfur-oxidizing bacterial endosymbionts: analysis of phylogeny and specificity by 16S rRNA sequences. J. Bacteriol. 170: 2506-2510

Doube, B. M. (1987). Spatial and temporal organization in communities associated with dung pads and carcasses. In: Gee, J., Giller, P. (eds.) Organization of communities: past and present. Blackwell Scientific, Oxford, p. 255-280

Embley, R. W., Eittreim, S. L., McHugh, C. H., Normack, W. R., Rau, G. H., Hecker, B., DeBevoise, A. E., Greene, H. G., Ryan, W. B., Harrold, C., Baxter, C. (1990). Geological setting of chemosynthetic communities in the Monterey Fan Valley system. Deep Sea Res. 37: 1651-1667

Emery, K. O. (1960). The sea off Southern California. John Wiley and Sons, New York

Fauchald, K., Jumars, P. A. (1979). The diet of worms: a study of polychaete feeding guilds. Oceanogr. mar. Biol. A. Rev. 17: $193-284$

Felbeck, H., Childress, J. J., Somero, G. N. (1983). Biochemical interactions between mollusks and their algal and bacterial symbionts. In: The Mollusca, Vol. 2, Environmental biochemistry and physiology. Academic Press, Orlando, p. 331-358

Fisher, C. R. (1990). Chemautotrophic and methanotrophic symbioses in marine invertebrates. Rev. Aquat. Sci. 2: $399-436$

Gage, J. D., Tyler, P. A. (1991). Deep-sea biology: a natural history of organisms at the deep-sea floor. Cambridge Univ. Press, Cambridge

Genin, A., Dayton, P. K., Lonsdale, P. F., Spiess, F. N. (1986). Corals on seamount peaks provide evidence of current acceleration over deep-sea topography. Nature 332: 59-61

Gibbs, P. E. (1987). A new species of Phascolosoma (Sipuncula) associated with a decaying whale's skull trawled at $880 \mathrm{~m}$ depth in the southwest Pacific. N.Z. J. Zool. 14: $135-137$

Grassle, J. F. (1986). The ecology of deep-sea hydrothermal vent communities. Adv. mar. Biol. 23: 301-362 
Grassle, J. F., Maciolek, N. J. (1992). Deep-sea species richness: regional and local diversity estimates from quantitative bottom samples. Am. Nat. 139: 313-341

Hanski, r. (1986). Individual behaviour, population dynamics and community structure of Aphodius (Scarabaejdae) in Europe. Acta Oecol. 7: 171-187

Hartley, H. O., Pearson, E. S. (1950). Table of the probability integral of the t-distribution. Biometrika 37: 1.68-172

Hessler, R. R., Smithey, W. M. Boudrias, M. A., Keller, C. H., Lutz, R. A., Childress, J. J. (1988). Temporal changes in megafauna at the Rose Garden hydrothermal vent (Galapagos Rift; eastern tropical Pacific). Deep Sea Res. 35: $1681-1709$

Hessler, R. R., Smithey, W. M., Keller, C. H. (1985). Spatial and temporal variation of giant clams, tube worms and mussels at deep-sea hydrothermal vents. Bull. Biol. Soc. Wash. 6 : $411-428$

Isaacs, J. D., Schwartzlose, R. A. (1975). Active animals of the deep-sea floor. Sci. Am. 233: 24-30

Jumars, P. A., Gallagher, E. D. (1982). Deep-sea community structure: three plays on the benthic proscenium. In: Ernst, W. G., Morin, J. L. (eds.) The environment of the deep sea. Prentice-Hall, Englewood Cliffs, NJ, p. 217-255

Juniper, K. M., Sibuet, M. (1987). Cold seep benthic communities in the Japan subduction zones: spatial organization, trophic strategies and evidence for temporal evolution. Mar. Ecol. Prog. Ser. 40: 115-126

Kennicutt, M. C., Brooks, J. M., Bidigare, R. R., Fay, R. R., Wade, T L., MCDonald, T J. (1985). Vent-type taxa in a hydrocarbon seep region on the Louisiana slope. Nature 317: $351-353$

Kennicutt, M. C., Brooks, J M., Bidigare, R. R., McDonald, J. J., Adkison, D. L., Macko, S. H. (1989). An upper slope 'cold' seep community: northern California. Limnol. Oceanogr. 34: 635-640

Kukert, H. (1989). In situ experiments on the response of deep-sea macrofauna burial disturbance. M.S. thesis, University of Washington, Seattle

Kukert, H., Smith, C. R. (1992). Disturbance, colonization and succession in a deep-sea sediment community: artificialmound experiments. Deep Sea Res. 39: 1349-1371

Kulm, L. D., Suess, E., Moore, J C., Carson, B., Lewis, B. T., Ritger, S. D., Kadko, D. C., Thornburg, T M., Embley, R. W., Rugh, W. D., Massoth, G. J., Langseth, M. G., Cochrane, G. R. Scamman, R. L. (1986). Oregon subduction zone: venting, fauna and carbonates. Science 31 : $561-566$

Lockyer, C. (1976). Body weights of some species of large whales. J. Cons. int. Explor. Mer 36: 259-273

MacDonald, I. R., Boland, G. S., Baker, J. S., Brooks, J M., Kennicutt, M. C. Il, Bidigare, R. R. (1989). Gulf of Mexico hydrocarbon seep communities. Mar. Biol. 101: 235-247

Marshall, B. A. (1987). Osteopeltidae (Mollusca: Gastropoda): a new family of limpets associated with whale bone in the deep sea. J. mollusc. Stud. 53: 121-127

Martill, D. M., Cruickshank, R. I., Taylor, M. A. (1991). Dispersal via whale bones. Nature 351. 193

Mayer, L., Shor, A. N. Clarke, J. H., Piper, D. J. W. (1988). Dense biological communities at $3850 \mathrm{~m}$ on the Laurentian Fan and their relationship to the deposits of the 1929 Grand Banks earthquake. Deep Sea Res. 35: 1235-1246

McLean, J. H. (1992). Cocculiniform limpets (Cocculinidae and Pyropeltidae) living on whale bone in the deep sea off California. J. mollusc. Stud. 58: 401-414

McLean, J. H., Haszprunar, G. (1987). Pyropeltidae, a new family of cocculiniform limpets from hydrothermal vents. Veliger 30: 196-205
Mullineaux, L. (1988). The role of settlement in structuring a hard-substratum community in the deep sea. J. exp. mar Biol. Ecol. 120: 247-261

Mullineaux, L. S. (1987). Organisms living on manganese nodules and crusts: distribution and abundance at three North Pacific sites. Deep Sea Res. 34: 165-184

Omura, H. (1971). A comparison of the size of vertebrae among some species of the baleen whales with special reference to whale movements. Scient. Rep. Whales Res. Inst. 23: 61-69

Paull, C. K., Hecker, B., Comeau, R., Freeman-Lynde, R. P., Neumann, C., Corso, W. P., Golubic, S., Hook, J. E., Sikes, E., Curray, J (1984). Biological communities at the Florida Escarpment resemble hydrothermal vent taxa. Science 226: 965-967

Pearson, T H., Rosenberg, R. (1978). Macrobenthic succession in relation to organic enrichment and pollution of the marine envrionment. Oceanogr. mar. Biol. A. Rev. 16: $229-31.1$

Pettibone, M. H. (1993). Polynoid polychaetes associated with a whale skeleton in the bathyal Santa Catalina Basin Proc. Biol. Soc. Wash. 106: 678-688

Rice, D. W., Wolman, A. A., Braham, H. W. (1984). The gray whale, Eschrichtius robustus. Mar. Fish. Rev. 46: 7-14

Rona, P. A., Klinkhammer, G., Nelson, T A., Trefry, J. H., Elderfield, H. (1986). Black smokers, massive sulphides and vent biota at the mid-Atlantic Ridge. Nature 321 $33-37$

Schäfer, W. (1972). Ecology and paleoecology of marine environments. University of Chicago Press, Chicago

Sibuet, M., Juniper, S. K., Pautot, G. (1988). Cold-seep benthic communities in the Japan subduction zones: geological control of community development. J. mar. Res. 46: $333-348$

Smith, C. R. (1983). Enrchment, disturbance and deep-sea community structure: the significance of large organic falls to bathyal benthos in Santa Catalina Basin. Ph.D. dissertation, University of California, San Diego

Smith, C. R. (1985). Food for the deep sea: utilization, dispersal and flux of nekton falls at the Santa Catalina Basin floor Deep Sea Res. 32: 417-442

Smith, C. R. (1986). Nekton falls, low-intensity disturbance and community structure of infaunal benthos in the deepsea. J. mar. Res. 44: 567-600

Smith, C. R. (1992a). Factors controlling bioturbation in deepsea sediments and their relation to models of carbon diagenesis. In: Rowe, G. T., Pariente, V. (eds.) Deep-sea food chains and the global carbon cycle. Kluwer, Dordrecht, p. $375-393$

Smith, C. R. (1992b). Whale falls: chemosynthesis on the deep-sea floor. Oceanus 36: 74-78

Smith, C. R., Hamilton, S. C. (1983). Epibenthıc megafauna of a bathyal basin off southern California: patterns of abundance, biomass and dispersion. Deep Sea Res. 30: 907-928

Smith, C. R., Jumars, P. A., DeMaster, D. D. (1986). In situ studies of megafaunal mounds indicate rapid sediment turnover and community response at the deep-sea floor Nature 323: 251-253

Smith, C. R., Kukert, H., Wheatcroft, R. A., Jumars, P. A., Deming, J. W. (1989). Vent fauna on whale remains. Nature 341: 27-28

Smith, K. L. Jr (1987). Food supply and demand: a discrepancy between particulate organic carbon flux and sediment community oxygen consumption in the deep ocean. Limnol. Oceanogr. 32: 201-220

Sokal, R. R., Rohlf, F. J. (1981). Biometry. W. H. Freeman, New York 
Somero, G. N., Childress, J. J., Anderson, A. E. (1989). Transport, metabolism and detoxification of hydrogen sulfide from sulfide-rich marine environments. Crit. Rev. mar. Sci. 1. $591-614$

Squires, R. L., Goedert, J. L., Barnes, L. G. (1991). Whale carcasses. Nature 349: 574

Tomilin, A. G. (1967). Mammals of the USSR and adjacent countries, Vol. IX, Cetacea. Israel Program for Scientific Translations, Jerusalem

Tunnicliffe, V. (1991). The biology of hydrothermal vents: ecology and evolution. Oceanogr. mar. Biol. A. Rev. 29: $319-407$

Tunnicliffe, $V$. (1992). The nature and origin of the modern hydrothermal vent fauna. Palaios 7: $338-350$

Van Dover, C. L. (1990). Biogeography of hydrothermal vent communities along seafloor spreading centers. Trends Ecol. Evol. 5: 242-246

This article was submitted to the editor
Van Dover, C. L., Berg, C. J., Turner, R. D. (1988). Recruitment of marine invertebrates to hard substrates at deep-sea hydrothermal vents on the East Pacific Rise and Galapagos spreading center. Deep Sea Res. 35: 1833-1849

Vetter, R. D. (1.985). Elemental sulfur in the gills of three species of clams containing chemoautotrophic symbiotic bacteria: a possible energy storage compound. Mar Biol. 88: $33-42$

Wakefield, W. W. Genin, A. (1987). The use of a Canadian (perspective) grid in deep-sea photography. Deep Sea Res. 34: 469-478

Wheatcroft, R. A. (1991). Conservative tracer studies of horizontal bioturbation rates in a bathyal basin, California borderland. J. mar. Res. 49: 565-588

Wheatcroft, R. A., Smith, C. R., Jumars, P. A. (1989). Dynamics of surficial trace assemblages in the deep sea. Deep Sea Res. 71-91

Manuscript first received: October 19, 1993

Revised version accepted: March 4, 1994 